\title{
Co-infection of Trichomonas vaginalis and HIV infection and its risk factors among prison inmates in Umuahia, Abia State, South Eastern Nigeria
}

Queen Ozioma Lawrence ${ }^{*}$ (I), Anthonia Nnenna Chuks Amadi, Chinenye Okosa, Paulinus Obeten Ikpi and Blessing Chigozie Chukwuemeka

\begin{abstract}
Background: A study was conducted to determine the co-infection of Trichomonas vaginalis and HIV infection prevalence and its risk factors among prison inmates in Umuahia, Abia State, Nigeria. A total of 350 inmates (280 males and 70 females) participated in the study. Three hundred and fifty (350) blood and urine samples including 70 high vaginal swabs (from females) were screened using direct serological and wet mount methods respectively. Structured questionnaire were administered to obtain socio-demographic and behavioral risk factor data.

Results: An overall prevalence $43.4 \%$ was recorded for Trichomonas vaginalis single infection and $2.6 \%$ for HIV single infection. A total of $8(2.3 \%)$ prevalence for Trichomonas vaginalis and HIV co-infection were recorded in our study. Females recorded more infection (2.8\%) than their male counterpart (2.1\%). Age groups 21-30 and 31-40 had highest prevalence in male and age group 31-40 in females. This study also identified multiple sex partners and unprotected sex as the major risk factors that influence transmission of T. vaginalis and HIV infection although was insignificant.

Conclusions: Prevalence of T. vaginalis and HIV co-infection was minimal, however, should not be ignored. Adequate healthcare facility should be provided in the prison. Inmates should be tested and treated upon their release to reduce the spread of the infection to the general population.
\end{abstract}

Keywords: Trichomonas vaginalis, Prevalence, Prison, Inmates, Co-infection, HIV, Risk factors

\section{Background}

Trichomoniasis caused by Trichomonas vaginalis is a sexually transmitted widely distributed disease as Chlamydia (Mabey, 2008). T. vaginalis is the most common non-viral sexually transmitted disease, with over 170 million cases occurring annually (Miller et al., 2005). Human immunodeficiency virus (HIV) belongs to group VI retrovirus which has about four stages that mature into acquired immunodeficiency syndrome (AIDS)

\footnotetext{
* Correspondence: queenlawrence8@gmail.com

Department of Zoology and Environmental Biology, Michael Okpara University of Agriculture Umudike, Umuahia, Abia State, Nigeria
}

(Koenig, Espinoza, Hodge, \& Ruffo, 2007). HIV infection is a primary infection which may be clinically asymptomatic at the initial stage but symptomatic at later stage then advance to AIDS (Miller et al., 2005). The virus attack the immune system by destroying the CD4 cells thereby weakening the immune system of the individual; progressing to AIDS, significantly increase the risk of opportunistic disease (Koenig et al., 2007; World Health Organisation, 2010).

HIV and parasitic infections may likely associate and affect the transmission of each other mutually (Van Der Pol et al., 2008). HIV infection may also alter the natural history of parasitic diseases, which may affect the 
diagnosis or reduce the efficacy of anti-trichomoniasis treatment (World Health Organisation, 2006). The relationship between $T$. vaginalis infection and HIV infection is similar to that between HIV infection and other STDs in that it may be vice versa (Van Der Pol et al., 2008). T. vaginalis infection may promote HIV transmission, and HIV infection may on the other hand increase susceptibility of $T$. vaginalis infection (Van Der Pol et al., 2008). Biological relationships between $T$. vaginalis and HIV that may affect susceptibility to HIV infection have been reported (Cohen et al., 1999).

T. vaginalis control may have a great impact on HIV acquisition prevention among the general population especially in HIV endemic area (World Health Organisation, 2006). Studies on the prevalence of $T$. vaginalis and HIV co-infection especially among prison inmates are rare. Therefore, the aim of this study was to determine the prevalence of $T$. vaginalis and HIV co-infection and its risk factors among prison inmates in Umuahia, Abia State.

\section{Methods}

A cross-sectional study was adopted for the purpose of this study which lasted between February and May 2017. The study was carried out in Umuahia Prison located at Aba road in Afara in Umuahia the capital of Abia state, South-Eastern Nigeria (Fig. 1). It is located on latitude $5^{\circ} 31^{\prime} 12.0^{\prime \prime} \mathrm{N}$ and longitude $7^{\circ} 29^{\prime} 16.8^{\prime \prime} \mathrm{E}$ in Nigeria. The average annual rainfall is $133.7 \mathrm{~mm}$ and temperature $74{ }^{\circ} \mathrm{C}$. The study area is within the tropical rainforest of eastern Nigerian states (within the ecological zones of Enugu, Akwa Ibom, Cross River, Ebonyi, Imo and Rivers States). Samples were examined in Zoology and Environmental Biology (ZEB) postgraduate laboratory, Michael Okpara University of Agriculture Umudike (MOUAU).

\section{Sample collection}

Urine samples and high vaginal swab (from females) were used for $T$. vaginalis screening while blood samples for HIV infection screening. A total of 350 urine samples from both male and female aged 18-61 years and 70

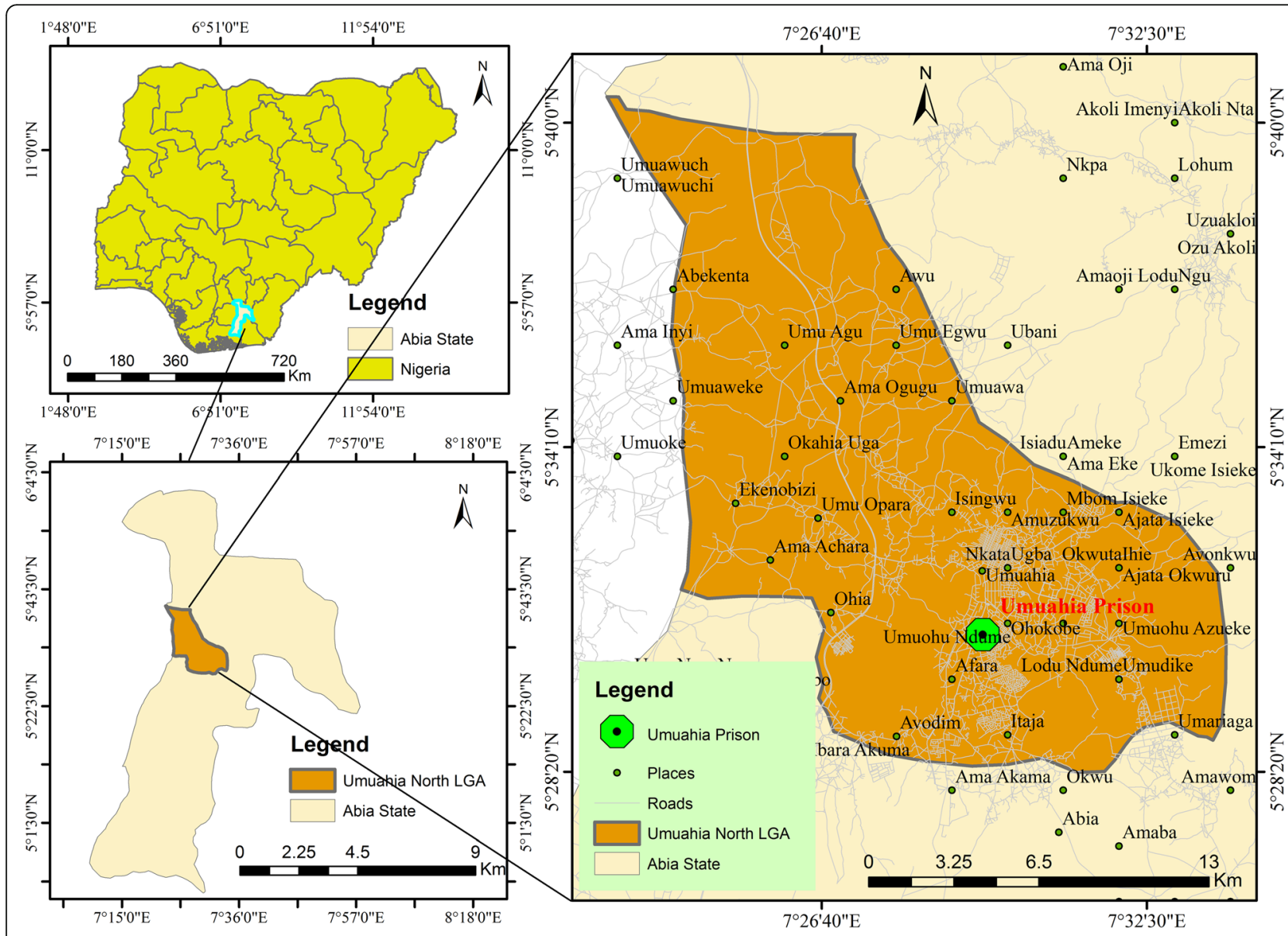

Fig. 1 Map of Umuahia showing the location of the Prison, Aba Road, Umuahia 
high vaginal swabs (HVS) (from female only) were collected using a labelled screwed capped bottle and vaginal swab stick respectively. Sterile capped bottles $(25 \mathrm{ml})$ were given to each participant labelled against their names and age along with a copy of a questionnaire to obtain their demographics. Long plastic sterile swab sticks was used by the prison health workers to collect exudates from the lower genital tract of female participants. Samples were transported to the Postgraduate Laboratory, Department of Zoology and Environmental Biology Department, Michael Okpara University of Agriculture, Umudike and screened according to Henry (1996) and Isenberg (1992).

Five milliliters of urine sample was transferred into centrifuge tubes and centrifuged for $8 \mathrm{~min}$ at $1500 \mathrm{rpm}$ and the supernatant fluid was decanted. The sediments were well-mixed and a drop of sediment was placed on a microscopic slide, covered with cover slide, and the slide was observed under the microscope using $\times 10$ and $\times 40$ objectives (Isenberg, 1992). Two drops of normal saline was added to each container of the vaginal swab and was mixed well by shaking and a drop of the mixture was placed on a slide, covered with cover slip, and examined under a light microscope using $\times 10$ and $\times 40$ objectives and was further confirmed by a senior laboratory technologist. Positive results were defined by the presence of one or more trichomonads characteristics morphology and jerky motility (Henry, 1996).

Sero-diagnosis of HIV antibodies in the blood samples were performed using parallel testing algorithm kit for HIV testing. Confirmation of each positive specimen was done using the double ELISA (enzyme-linked immunosorbent assay) kit. Acu-Check ${ }^{\circ}$ was used to clear all discordant results (Idoko, Njoku, Sirisena, \& Jelpe, 2001).

\section{Data analysis}

Chi-square analysis was used to test for associations between demographics and behavioral factors and prevalence. The association was considered significant when the $\mathrm{p}$ value was $<0.05$. Correlation analysis was used to check the relationship between co-infection and ages of the inmates. PAST Statistical Software (V. 3.1) was used for the statistical analysis (Hammer, Harper, \& Paul, 2001).

Table 1 Overall prevalence of Trichomonas vaginalis infection in relation to gender among inmates in Umuahia Prisons, Abia State

\begin{tabular}{lllll}
\hline Gender & No. examined & No. infected & \% Infected & $\boldsymbol{P}$ value \\
\hline Male & 280 & 94 & 33.6 & 0.05 \\
Female & 70 & 58 & 82.8 & \\
Total & $\mathbf{3 5 0}$ & $\mathbf{1 5 2}$ & $\mathbf{4 3 . 4}$ & \\
\hline
\end{tabular}

$x^{2}=18.3935, \mathrm{df}=1, p$ value $<0.05$
Table 2 Overall prevalence of HIV infection in relation to gender among the inmates in Umuahia Prison, Abia State

\begin{tabular}{lllll}
\hline Gender & No. examined & No. infected & \% Infected & P value \\
\hline Male & 280 & 5 & 1.7 & 0.07 \\
Female & 70 & 4 & 5.7 & \\
Total & $\mathbf{3 5 0}$ & $\mathbf{9}$ & $\mathbf{2 . 6}$ & \\
\hline
\end{tabular}

$x^{2}=3.20397, \mathrm{df}=1, p$ value $=0.07346$

\section{Results}

The overall prevalence of Trichomonas vaginalis infection was $43.4 \%$ (Table 1). Infection was higher among females $(82.8 \%)$ than in males (33.6\%). Chi-square analysis showed a significant difference in gender-related prevalence $(P<0.05)$.

The overall prevalence of HIV single infection was $2.6 \%$. Female recorded more infections (5.7\%) than the males $(1.7 \%)$ but there was no significant difference $(P>$ 0.05) (Table 2).

Some of the inmates had mixed/co-infection of Trichomonas vaginalis and HIV. A total of $2.3 \%$ prevalence was recorded (Table 3). This prevalence was almost close to the HIV single infection. Female inmate recorded higher prevalence (2.8\%) compared to males (2.1\%). The age groups: $21-30$ and $31-40$ had the highest prevalence in male but showed highest among age group 31-40 in female (Table 3). Correlation analysis showed a strong positive (0.956) relationship between the co-infection and ages of the male inmates but positive and weak (0.525) in females.

The participants were asked to provide information on their sexual behaviour and current STIs. Out of the 220 respondent who completed and returned their questionnaires, 105 (47.7\%) were infected with Trichomonas vaginalis. About $49.5 \%$ were aware of sexual risky behavior and its implication while $41.8 \%$ were not and $8.6 \%$ reported "no idea" (Table 4).

\section{Discussion}

Trichomonas vaginalis is among the sexually transmitted infections that is being neglected or even forgotten because they are not being reported like other infectious diseases (Soper, 2004). The overall prevalence for $T$. vaginalis single infection recorded in the present study was high compared to other related studies-Bakere et al. (2002) recorded $21 \%$ in Ibadan, Nigeria, Sutcliffe, Newman, Hardick, and Gaydos (2010) recorded 8.5\% in US Federal Prison and Zachariah et al. (2002) recorded $4.2 \%$ in rural District of Malawi. The prevailing conditions in Umuahia prison was that of poor sanitation and associated poor personal hygiene practices. Increased risk of $T$. vaginalis infection is common among persons with poor hygiene and low socioeconomic status (Omorodion, 2018). The recorded HIV prevalence 
Table 3 Prevalence of T. vaginalis and HIV co-infection among inmates in relation to age and gender in Umuahia Prison, Abia State

\begin{tabular}{|c|c|c|c|c|c|c|c|}
\hline \multirow{2}{*}{$\begin{array}{l}\text { Age } \\
\text { group }\end{array}$} & \multicolumn{3}{|l|}{ Male } & \multicolumn{3}{|l|}{ Female } & \multirow{2}{*}{$\begin{array}{l}\text { Total } \\
\text { (\%) } n \\
= \\
350\end{array}$} \\
\hline & No. examined & No. infected & $\begin{array}{l}\text { Percentage } \\
\text { (\%) Infected }\end{array}$ & No. examined & No. infected & $\begin{array}{l}\text { Percentage } \\
\text { (\%) infected }\end{array}$ & \\
\hline $18-20$ & 4 & 0 & 0.0 & 9 & 0 & 0.0 & $0(0.0)$ \\
\hline $21-30$ & 98 & 2 & 0.7 & 10 & 0 & 0.0 & $2(0.6)$ \\
\hline $31-40$ & 78 & 2 & 0.7 & 20 & 1 & 1.4 & $3(0.8)$ \\
\hline $41-50$ & 64 & 1 & 0.3 & 16 & 0 & 0.0 & $1(0.3)$ \\
\hline $51-60$ & 30 & 1 & 0.3 & 10 & 1 & 1.4 & $2(0.6)$ \\
\hline $60>$ & 6 & 0 & 0.0 & 4 & 0 & 0.0 & $0(0.0)$ \\
\hline Total & 280 & 6 & 2.1 & 70 & 2 & 2.8 & $8(2.3)$ \\
\hline
\end{tabular}

Male: $r=0.956$

Critical value: $\mathrm{r}_{0.01(2) 4}=0.917$

Female: $r=0.525$

agreed with the findings of Omoleye et al. (2012) among prison inmates in Abeokuta, Nigeria and Navadeh et al. (2013) in Iran and Gberindyer, Agbecha, Shindi, and Useh (2017) in Birnin Kebbi, Nigeria, who reported prevalence ranging between 2.1 and 2.7\%. However, higher prevalence of between $7 \%$ and $12 \%$ were reported by Joshua and Ogboi (2008) in Kaduna prison, Chima et al. (2009) in Nigeria prisons and Abba, Ibraheem, and Idoko (2014) in Jos prison, all in Nigeria. The low HIV prevalence recorded in the present study could be attributed to enlightenment campaigns and awareness programs which have improved the peoples' knowledge about the disease and its transmission, use of condoms, abstinence from sex, and non-rampant/less practices of promiscuous lifestyle. Higher prevalence in both $T$. vaginalis and HIV found among female inmates was in agreement with the findings of Chima et al. (2009) and Omoleye et al. (2012) conducted in Nigerian prisons. The susceptibility of females to sexually transmitted diseases is higher because of larger virginal surface that is

Table 4 Risk factors of Trichomonas vaginalis and HIV infection among the inmates in Umuahia Prisons, Abia State

\begin{tabular}{|c|c|c|}
\hline Variables & No. of respondents $(\%)(n=220)$ & $P$ value \\
\hline \multicolumn{3}{|c|}{$\begin{array}{l}\text { Are you aware of the risks factors associated with Trichomonas } \\
\text { vaginalis infection }\end{array}$} \\
\hline Yes & $109(49.5 \%)$ & 0.88 \\
\hline No & $92(41.8 \%)$ & \\
\hline No idea & $19(8.6 \%)$ & \\
\hline \multicolumn{3}{|c|}{ Do you practice unprotected sex } \\
\hline Yes & $85(38.6 \%)$ & 0.80 \\
\hline No & $135(61.3 \%)$ & \\
\hline \multicolumn{3}{|c|}{ Do you have multiple sexual partner } \\
\hline Yes & $135(61.3 \%)$ & 0.80 \\
\hline No & $85(38.6 \%)$ & \\
\hline
\end{tabular}

more vulnerable to sexual secretions (FHI 360, n.d.). Other studies on the prevalence of $T$. vaginalis and other STDs in men also showed that the infection is less prevalent in men than in women (Van der Pol, 2007). Additionally, wet mount microscopy is not an effective test for diagnosis of trichomoniasis in men, hence could contribute to the less prevalence recorded in the group (Van der Pol, 2007). However, the absence of trichomonads on urine microscopy of man does not rule out the presence of the infection in them.

The prevalence $(2.8 \%)$ for co-infection of $T$. vaginalis and HIV infection recorded was as low as HIV single infection prevalence $(2.6 \%)$ recorded in the present study. This result suggested that almost all the inmates who tested positive for HIV also tested positive for $T$. vaginalis infection. This is in agreement with conclusions drawn from related studies; Laga, Alarn, Nzila, et al., 1994; Rottingen, Cameron, \& Garnett, 2001; Sexton, Garnett, \& Rottingen, 2005 concluded that T. vaginalis infection was strongly associated with increase in HIV transmission. The presence of T. vaginalis infection increases the chances of HIV transmission and increase the burden of illness for HIV patients (Laga et al., 1994; Rottingen et al., 2001). T. vaginalis has shown to elicit an inflammatory response among infected individuals which in turn increase the appearance of HIV target cells (Howe \& Kissinger, 2017; Prince et al., 2006). HIV infection destroys the immune system thereby exposing the body to opportunistic infections including $T$. vaginalis. However, Davis, Dasgupta, Eckrich, and EL-Bassel, N. (2016) and Van Der Pol et al. (2008) reported higher co-infection prevalence of $5.10 \%$ and $36.4 \%$, respectively. The present study reported highest co-infection prevalence was among female inmates and could be attributed to the fact that females are more susceptible to sexually transmitted diseases (FHI 360, n.d.). Women are often more adversely affected by STIs than men (Amu \& Adegun, 2015; Davis et al., 2016). Another reason may be 
due to some factors which could lead to changes in the vaginal microbiota especially during menstruation which could lead to a decrease in glycogen production and $\mathrm{pH}$ changes thereby making a way for establishment and multiplication of these pathogens (Johnson, Petzold, \& Galask, 1985). This result is in agreement with Davis et al. (2016) that reported $4.8 \%$ prevalence of infected women for $T$. vaginalis and HIV co-infection in New York, USA; accounting for over one third of HIV positive women who also has $T$. vaginalis infection. The high co-infection prevalence recorded among age groups (21-30 and 31-40 years in males and $31-40$ years in females could be attributed to the high sexual activities among the age groups. Young people are more likely to engage in unprotected sex, have multiple sexual partners as well as get involved in trans-generational and transactional sex (Amu \& Adegun, 2015). Correlation analysis gives an insight into a possible two-way linear relationship between two continuous variables (Altman, 1990) and the stronger the correlation, the closer the correlation coefficient comes to \pm 1 (Mukaka, 2012). There was a strong positive relationship between co-infection prevalence and ages of the male inmates but positive and weak in females. Stewart (2007) observed that a great number of male prisoners between the age 21 and 39 years were pleasure seekers and have predisposition to having injection of drugs, multiple sexual partners, and sex with the same sex.

Even though multiple sexual partners and unprotected sex seem to be the major contributing factors to T. vaginalis transmission and HIV infection, our study found these variables insignificant to $T$. vaginalis and HIV transmission. This does not agree with similar studies where a strong significant relationship between having multiple sexual partners, unprotected sex, and transmission of T. vaginalis and HIV infection were reported (Ambrozio et al., 2016; Gewirtzman, Bobrick, Cornner, \& Stephen, 2011; Onyido et al., 2014).

However, some of the responses on the sexual activities of the inmates may not have been accurate as matters that concerns sexual life is often regarded as confidential. In a study conducted by Olugbenga, Adeoye, and Osagbem (2013), 14\% (14.9\%) of inmates practice sexual intercourse in prison, out of which $43.8 \%$ claimed to regularly use condoms. This is evidence that inmates engage in sexual activities before or during their stay in the prisons probably secretly as this is not condole in the prison.

\section{Conclusions}

The prevalence of HIV single infection was low and its co-infection with $T$. vaginalis, however, should not be neglected. Women are at higher risk of contracting STIs infections. Sticking to one sexual partner, a routine HIV and $T$. vaginalis screening could reduce the transmission of the STIs infection both among inmates and the general population. Adequate and improved health care should be provided in all prison institution and if possible inmates should be screened and treated before release. Awareness campaign will help to control these infections.

\section{Abbreviations}

HIV: Human immunodeficiency virus; AIDs: Acquired immunodeficiency virus; HVS : High vaginal swab; STDs: Sexually transmitted diseases; ZEB: Zoology and Environmental Biology; MOUAU: Michael Okpara University of Agriculture Umudike; ELISA: Enzyme-linked immunosorbent assay

\section{Acknowledgements}

The authors are grateful to all the inmates and staff of Umuahia Prison, Anyawu. E. D., Mr. Pipi Okechukwu and the Department of Zoology and Environmental Biology, Michael Okpara University of Agriculture, Umudike, Nigeria, for providing the necessary facilities used in this study.

\section{Authors' contributions}

LQO designed and drafted the work and was a major contributor in the writing of the manuscript. AANC revised and corrected the work. Authors OC, OPI, and CBC participated in the study design and data analysis. All authors read and approved the final manuscript.

\section{Funding}

No research funding was available for this study.

\section{Availability of data and materials}

All raw datasets generated and analysed were converted and arranged in a table format as shown in the "Results" section but are available from the corresponding author on reasonable request.

\section{Declarations}

\section{Ethics approval and consent to participate}

Permission was sought and obtained from the ethical board of Nigeria Correctional Services, Umuahia, Abia State (ABS/ SHQ/C.37NOL.111/907), Ethical Research Committee, Ministry of Health, Abia State (AB/MH/E\&HR/1/ 17/04) and Ethical Research Committee, College of Natural Sciences, Michael Okpara University of Agriculture, Umudike (CREEC/004/18). Informed consent was obtained from the inmates verbally along with a prison health worker by educating them on the need and relevance of the study. Reason for using verbal consent was to enable all inmates (who can read or not) understand fully what the research entails and this procedure was approved by the ethical board.

\section{Consent for publication}

Not applicable.

\section{Competing interests}

The authors declare that they have no competing interests.

Received: 17 June 2020 Accepted: 1 June 2021

Published online: 19 June 2021

\footnotetext{
References

Abba, O. J., Ibraheem, I. S., \& Idoko, J. A. (2014). Prevalence and risk factors for HIV/AIDS among male inmates in Jos prison, Plateau State, Nigeria. Nigerian Journal of Parasitology, 32(2), 181-186.

Altman, D. G. (1990). Practical Statistics for Medical Research, (1st ed., p. 624). Chapman \& Hall/CRC. https://doi.org/10.1201/9780429258589.

Ambrozio, C. L., Nagel, A. S., Jeske, S., Braganca, G. C. M., Borsuk, S., \& Villela, M. M. (2016). Trichomonas vaginalis prevalence and risk factor for women in Southern Brazil. Revista Do Instituto De Medicina Tropical De Sao Paulo, 58, 61. https://doi.org/10.1590/\$1678-9946201658061.

Amu, E. O. and Adegun, P. T. (2015). Awareness and knowledge of sexually transmitted infections among secondary school adolescents in Ado Ekiti,
} 
South Western Nigeria. Journal of Sexually Transmitted Diseases, Article ID 260126, 7. https://doi.org/10.1155/2015/260126.

Bakere, R. A., Oni, A. A., Umar, U. S., Fayemiwo, S. A., Fasina, N. A., Adewole, I. F., \& Shokunbi, W. A. (2002). Prevalence of Trichomonas vaginalis amongst commercial sex workers (CSW) in Ibadan, Nigeria. African Journal of Clinical and Experimental Microbiology, 3(2), 71-77.

Chima, C., Lab, H. F., Adebayo, S., Anyanti, J., Nwosu, A.N., Okekearu, I. and Mohammed, H. (2009). High HIV sero prevalence rates in prisons in Nigerian case of double sentencing for prison inmates. The Society for Family Health Rapid Assessment Report. http://www.sfhnigeria.org/nigeria\%2 OprisonsChima\%20et\%20Al\%20Poster\%20Final\%2D\%2D97×150cm.pdf. Accessed 10 Oct 2018.

Cohen, C. R., Plummer, F. A., Mugo, N., Maclean, I., Shen, C., Bukusi, E. A., ... Brunham, R. C. (1999). Increased interleukin-10 in the endocervical secretions of women with non-ulcerative sexually transmitted diseases: a mechanism for enhanced HIV-1 transmission. AIDS, 13(3), 327-332. https://doi.org/10.1 097/00002030-199902250-00004

Davis, A., Dasgupta, A., Eckrich, D., \& EL-Bassel, N. (2016). Trichomonas vaginalis and HIV co-infection among women under community supervision: a call for expanded T. vaginalis screening. Sex Transmitted Disease, 4(10), 617-622.

FHI 360 (n.d.). Sexually Transmitted Diseases. Women at Risk. Family Health International https://www.fhi360.org/sites/default/files/webpages/Modules/ STD/s1pg22.htm. Accessed 10 May 2020.

Gberindyer, J. S., Agbecha, A., Shindi, J., \& Useh, N. (2017). Human immunodeficiency virus infection among male prison inmates in Birnin Kebbi, Nigeria. Environmental Disease, 2(1), 27-31.

Gewirtzman, A., Bobrick, L., Cornner, K., \& Stephen, K. T. (2011). Epidemiology of sexually transmitted infections. In Centre for Clinical Studies, Houston, Texas USA, (pp. 13-34).

Hammer, Ø., Harper, D. A. T., \& Paul, D. R. (2001). PAST: Paleontological Statistics Software Package for Education and Data Analysis. Paleontologia Electronica. 4(1), article $49,178 \mathrm{~kb}$.

Henry, J. B. (1996). Clinical diagnosis and management by laboratory methods, (19th ed., pp. 220-223). Published by W.B Saunders Co Ltd.

Howe, K., \& Kissinger, P. J. (2017). Single-Dose Compared with Multidose Metronidazole for the Treatment of Trichomoniasis in Women: meta-Analysis. Sexually Transmitted Diseases, 44(1), 30-35. https://doi.org/10.1097/OLQ. 0000000000000537

Idoko, J. A., Njoku, M. O., Sirisena, M. D., \& Jelpe, D. (2001). CD CD $_{4}$ T-Lymphocyte counts in Human Immunodeficiency Virus (HIV) infected and healthy Nigerian populations. The Nigerian Medical Practitioner, 39, 53-56.

Isenberg, H.D. (1992). Clinical Microbiology Procedure Handbook. American Society of Microbiology 1(2), 382.

Johnson, S. R., Petzold, C. R., \& Galask, R. P. (1985). Qualitative and quantitative changes of the vaginal microbial flora during the menstrual cycle. American Journal of Reproductive Immunology and Microbiology, 9(1), 1-5. https://doi. org/10.1111/j.1600-0897.1985.tb00331.X.

Joshua, I. A., \& Ogboi, S. J. (2008). Seroprevalence of human immunodifficiency (HIV) virus amongst inmates of Kaduna Prison, Nigeria. Science World Journal, 3(1), 17-19. https://doi.org/10.4314/swj.v3i1.51765.

Koenig, L. J., Espinoza, L., Hodge, K., \& Ruffo, N. (2007). Young, seropositive and pregnant: epidemiologic and psychosocial perspectives on pregnant adolescents with human immunodeficiencyVirus Infection. American Journal of Obstetric Gynocology, 197(3), 123-131. https://doi.org/10.1016/j.ajog.

Laga, M., Alarn, M., Nzila, N., et al. (1994). Condom promotion, sexually transmitted diseases treatment, and declining incidence of HIV-1 infection in female Zairian sex workers. Lancet, 344(8917), 246-248. https://doi.org/10.101 6/50140-6736(94)93005-8.

Mabey, D. (2008). Interactions between HIV infections and other sexually transmitted diseases. Tropical Medicine and Internal Health, 5, 32-36.

Miller, W. C., Swygard, H., Hobbs, M. M., Ford, C. A., Handcock, M. S., Morris, M., ... Udry, J. R. (2005). The prevalence of trichomoniasis in young adults in the United States. Sex Transmitted Disease, 32(10), 593-598. https://doi.org/10.1 097/01.olq.0000179874.76360.ad.

Mukaka, M. M. (2012). Statistics corner: a guide to appropriate use of correlation coefficient in medical research. Malawi Medical Journal, 24(3), 69-71.

Navadeh, S., Mirzaadeg, A., Gouya, M. M., Farnia, M., Alasvand, R., \& Haghdoost, A. (2013). HIV prevalence and related risk behaviours among prisoners in Iran: results of the national biobehavioral survey. Sex Transmitted Infection, 89(3), 33-36. https://doi.org/10.1136/sextrans-2013-051295.
Olugbenga, B. O., Adeoye, A., \& Osagbem, K. G. (2013). Assessment of the reproductive health status of adult prison inmates in Osun State, Nigeria. International Journal of Reproductive Medicine. Article ID: 451460, 9.

Omoleye, T., Muhammeda, O., Matthew, A., Glory, O., Atilola, A. I., \& Komolafe, O. O. (2012). Seroprevalence of HIV/AIDS and HIV risk factors among prison inmates in Ogun State, Nigeria. HIV \& AIDS Review, 11, 25-30.

Omorodion, O. A. (2018). Trichomoniasis in Nigeria: a review. Biomedical Research. https://doi.org/10.4066/biomedicalresearch.29-18-493.

Onyido, A. E., Umeanaeto, P. U., Irikannu, K. C., Ekwunife, C. A., Ezeanya, L. C., Nwangwu, U. C., ... Obiechina, I. O. (2014). Prevalence of Trichomonas vaginalis among the rural women of Ekwulumili Community Anambra State, Southeastern Nigeria. Nature Science, 12(5), 129-134 http://www.sciencepub. net/nature.

Prince, M., Stewart, S. R., Miller, W. C., Behets, F., Dow, W. H., \& Martinson, F. E. (2006). The cost-effectivensess of treating male trichomonaiasis to avert HIV transmission in men seeking sexually transmitted disease care in Malawi. Journal of Acquired immune Deficiency Syndromes, 43(2), 202-209. https://doi. org/10.1097/01.qai.0000229014.39451.33.

Rottingen, J. A., Cameron, D. W., \& Garnett, G. P. (2001). A systematic review of the epidemiologic interactions between classic sexually transmitted diseases and HIV: how much is really known? Sexually Transmitted Disease, 28(10), 579-597. https://doi.org/10.1097/00007435-200110000-00005.

Sexton, J., Garnett, G. P., \& Rottingen, J. (2005). Meta-analysis and metaregression in interpreting study variability in the impact of sexually transmitted diseases on susceptibility to HIV infection. Sex Transmitted Disease, 32(6), 351-357. https://doi.org/10.1097/01.olq.0000154504.54686.d1.

Soper, D. (2004). Trichomoniasis: under control or undercontrolled? American Journal of Obstetrics and Gynaecology., 190(1), 281-290. https://doi.org/10.101 6/j.jjog.2003.08.023.

Stewart, E. C. (2007). The sexual health and behaviour of male prisoners. The Howard Journal, 46(1), 43-59. https://doi.org/10.1111/j.1468-2311.2007.00453. $x$.

Sutcliffe, S., Newman, S. B., Hardick, A., \& Gaydos, C. (2010). Prevalence and correlates of Trichomonas vaginalis infection among female US federal prison inmates. Sexually Transmitted Disease, 37(9), 585-590. https://doi.org/10.1097/ OLQ.0b013e3181de4113.

Van der Pol, B. (2007). Trichomonas vaginalis infection: the most prevalent nonviral sexually transmitted infection receives the least public health attention. Clinical Infectious Disease, 44(1), 23-25.

Van Der Pol, B., Kwok, C., Pierre-Louis, B., Rinaldi, A., Salata, R. A., Chen, P. L., ... Morrison, C. S. (2008). Trichomonas vaginalis infection and human immunodeficiency virus acquisition in African women. Journal of Infectious Disease, 197(4), 548-554.

World Health Organisation (2006) AIDS epidemic update. http:/www.who.int/ hiv/pub/epidemiology/epiupdate2006/en/ (Internet information) Accessed on June 2017

World Health Organization (2010) Anti-retroviral therapy for HIV infection in adults and adolescents: recommendations for public health approach. Geneva: ISBN-13: 978-92-4-159976-4.

Zachariah, R., Harries, A. D., Chantulo, A., Yadidi, A. E., Nkhoma, W., \& Maganga, O. (2002). Sexually transmitted infections among prison inmates in a rural district of Malawi. Transactions of the Royal Society of Tropical Medicine and Hygiene, 96(6), 617-619. https://doi.org/10.1016/S0035-9203(02)90330-5.

\section{Publisher's Note}

Springer Nature remains neutral with regard to jurisdictional claims in published maps and institutional affiliations. 